University of Nebraska - Lincoln

DigitalCommons@University of Nebraska - Lincoln

USDA Forest Service / UNL Faculty Publications U.S. Department of Agriculture: Forest Service -National Agroforestry Center

2010

\title{
Population trends in northern spotted owls: Associations with climate in the Pacific Northwest
}

\author{
Elizabeth M. Glenn \\ Oregon State University \\ Robert G. Anthony \\ Oregon State University \\ Eric D. Forsman \\ USDA Forest Service
}

Follow this and additional works at: https://digitalcommons.unl.edu/usdafsfacpub

Part of the Forest Sciences Commons

Glenn, Elizabeth M.; Anthony, Robert G.; and Forsman, Eric D., "Population trends in northern spotted owls: Associations with climate in the Pacific Northwest" (2010). USDA Forest Service / UNL Faculty Publications. 159.

https://digitalcommons.unl.edu/usdafsfacpub/159

This Article is brought to you for free and open access by the U.S. Department of Agriculture: Forest Service -National Agroforestry Center at DigitalCommons@University of Nebraska - Lincoln. It has been accepted for inclusion in USDA Forest Service / UNL Faculty Publications by an authorized administrator of DigitalCommons@University of Nebraska - Lincoln. 


\title{
Population trends in northern spotted owls: Associations with climate in the Pacific Northwest
}

\author{
Elizabeth M. Glenn ${ }^{\mathrm{a}, *}$, Robert G. Anthony ${ }^{\mathrm{b}}$, Eric D. Forsman ${ }^{\mathrm{c}}$ \\ ${ }^{a}$ Department of Fisheries and Wildlife, Oregon State University, Corvallis, OR 97331, USA \\ ${ }^{\mathrm{b}}$ US Geological Survey, Oregon Cooperative Fish and Wildlife Research Unit, Department of Fisheries and Wildlife, Oregon State University, Corvallis, OR 97331, USA \\ ' USDA Forest Service, Pacific Northwest Research Station, Forestry Sciences Laboratory, Corvallis, OR 97330, USA
}

\section{A R T I C L E I N F O}

\section{Article history:}

Received 17 March 2010

Received in revised form 17 June 2010

Accepted 21 June 2010

Available online 16 July 2010

\section{Keywords:}

Adult survival

Barred owl

Climate

Rate of population change

Recruitment

Strix occidentalis caurina

Weather

\begin{abstract}
A B S T R A C T
We used reverse time capture-mark-recapture models to describe associations between rate of population change $(\lambda)$ and climate for northern spotted owls (Strix occidentalis caurina) at six long-term study areas in Washington and Oregon, USA. Populations in three of six areas showed strong evidence of declining populations, while populations in two additional areas were likely declining as well. At four areas, $\lambda$ was positively associated with wetter-than-normal conditions during the growing season, which likely affects prey availability. Lambda was also negatively associated with cold, wet winters and nesting seasons, and the number of hot summer days. The amount of annual variation in $\lambda$ accounted for by climate varied across study areas (3-85\%). Rate of population change was more sensitive to adult survival than to recruitment; however, there was considerable variation among years and across study areas for all demographic rates. While annual survival was more closely related to regional climate conditions, recruitment was often associated with local weather. In addition to climate, declines in recruitment at four of six areas were associated with increased presence of barred owls. Climate change models predict warmer, wetter winters and hotter, drier summers for the Pacific Northwest in the first half of the 21st century. Our results indicate that these conditions have the potential to negatively affect annual survival, recruitment, and consequently population growth rates for northern spotted owls.
\end{abstract}

(ㄷ) 2010 Elsevier Ltd. All rights reserved.

\section{Introduction}

Two decades of research have documented declines in northern spotted owl (Strix occidentalis caurina) populations across the Pacific Northwest (Anderson and Burnham, 1992; Burnham et al., 1994; Anthony et al., 2006; Forsman et al., in press). To meet requirements of the Endangered Species Act and National Forest Management Act, federal agencies adopted the Northwest Forest Plan (NWFP) in 1994 (USDA and USDI, 1994) as a conservation strategy for the subspecies. Under this plan, conservation efforts for the spotted owl have focused on protection of late-successional forests on federal lands throughout its geographic range. Because of the contentious debate over how best to manage late-successional forests for the spotted owl (S. o. caurina, S. o. occidentalis), it has become one of the most studied bird species in the world. In addition to numerous reports on population trends, there have also been many studies of habitat use and home range size (Forsman et al., 1984, 2005; Carey et al., 1990; Glenn et al., 2004), diet (Barrows and Barrows, 1980; Forsman et al., 1984; Forsman et al.,

\footnotetext{
* Corresponding author. Tel.: +1 5412315230.

E-mail address: betsyglenn1@gmail.com (E.M. Glenn).
}

2001, 2004), genetics (Barrowclough et al., 1999), prey ecology (Carey et al., 1992; Rosenberg et al., 2003; Forsman et al., 1994; Zabel et al., 1995), and dispersal (Forsman et al., 2002; Blakesley et al., 2006). Despite the extensive research, the effectiveness of the NWFP strategy for conserving northern spotted owls remains unclear (Courtney et al., 2004). Populations have shown continued declines since the early 1990s, and specific causes of declines have not been well-identified (Anthony et al., 2006; Forsman et al., in press). Conservation efforts have been further complicated by the range expansion of the congeneric barred owl (Strix varia) into the range of the northern spotted owl, with negative effects on site occupancy by spotted owls (Olson et al., 2005). Furthermore, both annual survival and reproduction have been shown to be affected by density-independent factors such as weather, in addition to habitat conditions (Franklin et al., 2000; Olson et al., 2004; Dugger et al., 2005).

Although both habitat and local weather have been shown to influence survival and reproduction (Franklin et al., 2000; Olson et al., 2004), effects of environmental variation on $\lambda$ have not been addressed for this subspecies. Franklin et al. (2000) proposed that even with unchanging habitat conditions, spotted owl populations could decline solely as a consequence of variation in weather. Under a global climate change scenario, potential effects of weather 
on population growth rate could be much greater, as changes in both the mean and variance of temperature, precipitation, and weather extremes are predicted (Mote et al., 2008). In order to understand the potential effects of climate change on population persistence, we first need to understand effects of naturally-occurring climate fluctuations on spotted owl populations.

Our goal was to evaluate hypotheses regarding associations between climate and realized rate of population growth (hereafter $\lambda$ ) of northern spotted owls at six study areas in Washington and Oregon that span most of the range of this subspecies. Because population growth rate is a function of both annual survival and recruitment (Nichols and Hines, 2002), we modeled relationships between climate and these two demographic rates to assess associations with $\lambda$. First, we evaluated hypotheses regarding associations between climate and both annual survival and recruitment. Second, we determined how much annual variation in demographic rates could be accounted for by weather and climate. Third, we determined the relative contributions of annual survival and recruitment to $\lambda$. We predicted that climate associations would differ across study areas and among demographic rates; however, we expected recruitment would be more strongly affected by climate than survival while $\lambda$ would be most sensitive to variation in annual survival.

\section{Methods}

\subsection{Study areas}

We examined associations between weather and climate and annual rate of population change $(\lambda)$ of northern spotted owls at six study areas in Washington and Oregon: Olympic peninsula (OLY) $\left(3289 \mathrm{~km}^{2}\right)$, Cle Elum (CLE) $\left(1784 \mathrm{~km}^{2}\right)$, H.J. Andrews (HJA) $\left(1526 \mathrm{~km}^{2}\right)$, Oregon Coast Range (OCR) $\left(3919 \mathrm{~km}^{2}\right)$, Tyee (TYE) $\left(1714 \mathrm{~km}^{2}\right)$, and Southern Oregon Cascades (CAS) $\left(3375 \mathrm{~km}^{2}\right)$. These 6 areas were part of the Monitoring Plan for the northern spotted owl under the NWFP (Lint et al., 1999) and are described in detail in Anthony et al. (2006) and Glenn (2009). OLY, HJA, and CAS were primarily federal lands, while CLE, OCR, and TYE were a mixture of federal, state, and private lands. TYE, OCR, and CAS contained lands administered by the US Bureau of Land Management with an ownership pattern of alternating sections $\left(2.56 \mathrm{~km}^{2}\right)$ of federal and private lands.

All study areas were characterized by mountainous terrain, but elevations in the coastal areas in Oregon (OCR, TYE) rarely exceeded $1250 \mathrm{~m}$. The remaining areas in the Cascades (CAS, HJA, CLE) and Olympic Peninsula (OLY) had mountain peaks well above timberline. Vegetation was dominated by mesic coniferous forests of Douglas-Fir (Pseudotsuga menziesii) and western hemlock (Tsuga heterophylla) on the OLY, OCR, HJA and TYE areas, and by mixedspecies associations of Douglas-fir, white fir (A. concolor), grand fir (A. grandis), and various pines (Pinus ponderosa, Pinus lambertiana, Pinus monticola, Pinus contorta) on the CLE and CAS areas (Franklin and Dyrness, 1973). Forest structure varied widely within and among areas, ranging from young forests on recently planted clear-cuts to unharvested forests that were $>400$ years old. All study areas contained large amounts of mature (80-200 yrs old) and old-growth ( $>200 \mathrm{yrs}$ old) forest, but these age classes were most common on the OLY, HJA, and CAS areas, where $>35 \%$ of the landscape was covered by mature and old-growth forest.

Climate also varied across the six areas. Areas in the central (HJA, CAS) or eastern Cascades (CLE) were characterized by warm, dry summers and cool winters, with most precipitation occurring as snow during winter months. At OLY and OCR, climate was maritime with most precipitation falling as rain during winter months, although snow was present at higher elevations at OLY. At TYE, cli- mate was similar to OLY and OCR, although summers were warmer and drier than more coastal areas.

\subsection{Field methods}

Owls were monitored at the six study areas beginning 1985-1991 and continuing through 2005 for all areas except OLY, which was monitored through 2003. Field methods followed Franklin et al. (1996), and data collection was standardized across all areas for all years (Anthony et al., 2006). Capture was defined as the physical capture of an individual or visual identification of marked owls with unique color-bands in subsequent years. Capture histories were developed for banded individuals $\geqslant 1$ year old.

Because other studies have found that resighting probabilities increased as researchers became more familiar with owls on a study area, we followed the protocol of Anthony et al. (2006) where the first 1-5 years of data were removed from capture history records to reduce potential bias in $\lambda$ associated with initial location and banding of owls during the first few years of study. Anthony et al. (2006) also determined that territories at our six study areas were not initially saturated with owls at the start of the survey period; thus, there was room for expansion in these populations.

\subsection{Statistical methods}

We used an information-theoretic approach (Burnham and Anderson, 2002) and reverse time capture-mark-recapture (CMR) models for open populations (Nichols and Hines, 2002; Pradel, 1996) in Program MARK (White and Burnham, 1999) to rank a priori models representing hypotheses regarding effects of weather and climate on annual survival $(\varphi)$, recruitment $(f)$, and $\lambda$. We used the survival-recruitment model parameterization, and estimated year-specific rates for $\lambda, \varphi, f$, as well as the relative contributions of $\varphi$ and $f$ to $\lambda$ (Nichols and Hines, 2002). We evaluated goodness-of-fit and obtained estimates of the overdispersion parameter $(\hat{c})$ for each data set using program RELEASE (Burnham et al., 1987). We used $\mathrm{AIC}_{\mathrm{c}}$ or $\mathrm{QAIC}_{\mathrm{c}}$ to rank models, $\mathrm{AIC}_{\mathrm{c}}$ or $\mathrm{QAIC}_{\mathrm{c}}$ weights $(w)$ to assess the likelihood of a given model, and used model-averaged parameter estimates for $\varphi, f$, and $\lambda$ (Burnham and Anderson, 2002).

Our estimates of $\lambda$ reflected changes in population size due to births, deaths, and movement in or out of the study area. Because juvenile owls have a high probability of emigrating from the study areas, capture histories used in our analyses were restricted to territorial owls that were $\geqslant 1.0$ year old. Therefore, $\lambda$ refers to the rate of population change of non-juvenile owls on nesting territories in each study area. Additionally, we incorporated a onetime increase in study area boundaries at OLY, HJA, and CAS to include areas surveyed outside the original boundaries incorporated following methods of Anthony et al. (2006).

We used a multistep process for evaluating our hypotheses. First, we identified the best model structure for recapture probabilities by evaluating demographic (sex, reproduction (REPROD), and barred owl presence (BO)) and time effects (time-varying, evenodd year, and time trend models) (Supplementary material 1 ). Second, we evaluated a small set of models that considered demographic and climate effects on annual survival. We first identified the most important demographic factors and then considered climate factors. This a priori set of models was based on previous studies that examined relationships between survival of northern spotted owls and climate (Franklin et al., 2000; Olson et al., 2004; Dugger et al., 2005; Glenn, 2009) as well as broader research on associations between avian demographic rates and climate. Finally, we modeled recruitment $(f)$, which is defined as the probability of an individual entering the territorial population on a study area. Recruitment is the result of in situ reproduction, 
survival of juvenile owls until they are recruited into the territorial population, and immigration of transient owls from outside the study area. To model recruitment, we considered a priori models which contained demographic and climatic factors that we hypothesized might be associated with either reproduction, annual survival, or both.

For each demographic rate, we had numerous statistical models representing our a priori hypotheses (Supplementary material 2). We evaluated the set of $a$ priori statistical models to identify which hypotheses were most supported and which statistical model best represented a given hypothesis. If models representing more than one hypothesis were supported, we also considered combinations of $a$ priori models if they made sense biologically and did not contain redundancies. We also evaluated different combinations of the competing models on survival and recruitment in cases where several models were competitive for survival, recruitment, or resighting rates to identify factors with the strongest association with a particular demographic rate. Our final models represented our $a$ priori hypotheses, but also included a small number of posteriori models (1-5 per study area).

We used the variance components module in Program MARK to compute estimates of temporal process variation (White et al., 2002). Year-specific seniority rates $\left(\gamma_{l}=\frac{\hat{\varphi}}{\hat{\lambda}}\right)$ were calculated from the time-specific estimates of $\varphi$ and $\lambda$ following methods of Nichols and Hines (2002), and were used to assess the relative contribution of annual survival to $\lambda$ (Nichols et al., 2000; Nichols and Hines, 2002).

\subsection{Hypotheses regarding associations between climate and rate of population change}

Our a priori hypotheses addressed associations between climate and both annual survival and recruitment (Supplementary material 2). We hypothesized that associations between annual survival and climate would be similar to effects reported in earlier studies (Franklin et al., 2000; Olson et al., 2004; Dugger et al., 2005; Glenn, 2009), although we anticipated that climate associations would vary among study areas. We developed four biological hypotheses regarding potential relationships between weather and annual survival, as follows: (1) survival would be negatively associated with cold, wet, stormy, or snowy winters or nesting seasons as a result of exposure, decreased foraging efficiency, or decreased prey populations (Franklin et al., 2000; Olson et al., 2004; Glenn, 2009); (2) survival would be positively associated with wetter conditions during the growing season (May-October) as small mammal populations, the primary prey of spotted owls, tend to increase in more mesic conditions (Luoma et al., 2003); (3) survival would be negatively associated with the number of hot days (DAYS $\geqslant 32^{\circ} \mathrm{C}$ ) during summer as spotted owls are better adapted to cold conditions than hot (Weathers et al., 2001), and (4) survival would be associated with regional climate cycles (Southern Oscillation, Pacific Decadal Oscillation) which assess temperature, moisture, and storm conditions at larger temporal and spatial scales (Glenn, 2009). For climate cycles, we considered associations with both the current year and prior year (1-year lag). For models containing precipitation, we considered both linear and quadratic relations as we hypothesized that changes in survival may be associated with deviations from average precipitation levels.

For modeling recruitment, we hypothesized that climatic factors associated with both reproduction and annual survival would be important. In general, we predicted that survival and reproduction would be similarly affected by weather; however, we hypothesized that cold, wet, or stormy nesting seasons would have a stronger negative effect on reproduction and consequently recruitment than with survival. We also considered lags of up to 3 years with climate factors associated with recruitment, as owls often to do not enter the territorial population for several years after fledging (Forsman et al., 2002).

\subsection{Demographic and climatic data}

Demographic covariates in models included gender, proportion of spotted owl territories with barred owl detections in a given year (BO), and mean number of young fledged per pair per year (REPROD) to evaluate associations between reproductive output and survival and increased resighting probabilities in years with high reproduction (Supplementary information 3). We also evaluated time-varying and time trend models for survival, recapture, and recruitment. In addition, we included an even-odd year effect on recruitment as northern spotted owls have shown an alternating year pattern in reproductive output in many areas of their range (Anthony et al., 2006).

We used Parameter Elevated Regression on Independent Slope Models (PRISM) maps (Oregon Climate Service, Oregon State University, Corvallis, OR, USA) to obtain mean monthly minimum temperature $\left({ }^{\circ} \mathrm{C}\right)(\mathrm{TMIN})$, mean monthly maximum temperature $\left({ }^{\circ} \mathrm{C}\right)$ (TMAX), and monthly precipitation ( $\mathrm{cm}$ ) (PRECIP) data for each study area. Temperature and precipitation data were compiled for each study area for seasonal time periods associated with spotted owl life history stages (Franklin et al., 2000; Olson et al., 2004): early nesting season (EN)(March-April), late nesting season (LN)(May-June), summer (S)(July-August), dispersal (D)(September-October), and winter (W)(November-February), as well as annually (A)(July-June). We used a GIS (ArcGIS) to combine monthly maps into seasonal and annual maps for our study areas for our time periods of interest.

Total annual snowfall $(\mathrm{cm})$ (SNOW), total number of days each year with a maximum daily temperature $>32^{\circ} \mathrm{C}$ (DAYS $\geqslant 32^{\circ} \mathrm{C}$ ), and numbers of days with stormy conditions during different seasonal periods for the six study areas were obtained using National Climatic Data Center (NCDC) weather station data (NOAA, 2008). Each study area contained 4-13 weather stations that consistently recorded SNOW and \# DAYS $\geqslant 32{ }^{\circ} \mathrm{C}$ for the time periods of interest. We averaged data across stations to obtain a single measure of SNOW and \# DAYS $\geqslant 32^{\circ} \mathrm{C}$ for each study area for each year. The NCDC Storm Database (NOAA, 2008) provided on-line records of days with heavy precipitation, temperature extremes, snow and ice, and high winds and thunderstorms. Storm data were organized by state and county, which enabled us to tally numbers of days with storm events for our time periods separately for each study area.

We used the Palmer Drought Severity Index (PDSI) to assess moisture levels during the growing season. The PDSI measures deviations of moisture conditions from normal (30-year mean: 1970-2000) on a standardized scale so comparisons can be made across regions and over time (NOAA, 2008). The index was calculated separately for climate regions within each state. Most study areas fell within one climate region. For study areas that included multiple climate regions, we used a weighted average of PDSI values based on the proportion of the study area that fell within each climate region.

To assess region-wide climate patterns, we used the Southern Oscillation (el Niño) Index (SOI) and the Pacific Decadal Oscillation Index (PDO). We obtained monthly values for the SOI and PDO indices from NOAA/National Weather Service, Climate Prediction Center (http://www.cpc.ncep.noaa.gov/data/indices/), and Joint Institute for the Study of the Atmosphere and Ocean at the University of Washington (http://jisao.washington.edu/pdo/PDO.latest), respectively. Negative SOI values (el Niño) are associated with warmer, drier winters in the Pacific Northwest, while positive SOI values (la Niña) are associated with cold, wet, snowy winters. Positive PDO values (warm phase) are associated with lower rainfall and 
higher temperatures in the Pacific Northwest, while negative values (cool phase) are associated with higher precipitation and cooler temperatures. We averaged monthly SOI and PDO values to obtain annual (July 1-June 30 ) measures for these indices.

\section{Results}

Analyses were based on capture histories for 2110 individual owls on the six study areas. OCR had the greatest number of owls (423) while CLE had the least (142) (Supplemental information 1). TYE and HJA had 15 years of capture history data included in the analyses, while the remaining areas had 13 years. Estimates of overdispersion from Program RELEASE ranged from 1.0 at CLE to 2.52 at OLY. We used $\mathrm{AIC}_{\mathrm{c}}$ to rank models at CLE and $\mathrm{QAIC}_{\mathrm{c}}$ for remaining areas.

\subsection{Weather and climate}

Weather and climate conditions during our study varied among years and study areas (Supplemental information 4). Daily mean temperature was highest at $\mathrm{OCR}\left(\bar{x}=11.84{ }^{\circ} \mathrm{C}, \mathrm{SE}=0.135\right)$ and lowest at $\operatorname{CLE}\left(\bar{x}=5.58^{\circ} \mathrm{C}, \mathrm{SE}=0.127\right)$, while mean annual precipitation was highest at OLY $(\bar{x}=287 \mathrm{~cm}, \mathrm{SE}=15.04)$ and lowest at CAS $(\bar{x}=114 \mathrm{~cm}, \mathrm{SE}=7.97)$. CAS, CLE, and TYE were relatively dry compared to OLY, OCR, and HJA. Although patterns varied by study area, 1996-1997 and 1998-1999 were generally the wettest years while 1991-1992, 1992-1994, 2000-2001, and 2004-2005 were the driest. Similarly, 1991-1992 and 2003-2004 were warm years; however, there was not a consistent pattern for cold years across study areas. Temperature and precipitation varied seasonally as well as annually, with high precipitation in winter and early nesting season and relatively dry conditions during summer through early fall at all areas.

The highest storm frequencies occurred in 1994-1998, which was consistent with the number of years with highest precipitation. The OCR study area, which was the most coastal of the 6 areas, had the greatest number of storm days per year over the duration of the study $(\bar{x}=20.4, \mathrm{SE}=2.13$ ), while CAS had the fewest $(\bar{x}=7.52$, SE $=0.73)$. Snowfall was consistently highest at CLE; variable at HJA, CLE, and OCR; and low at OLY and TYE. Number of DAYS $\geqslant 32{ }^{\circ} \mathrm{C}$ was cyclic at most areas between 1993 and 1999 , where even-numbered years (e.g. 1994) had more \# DAYS $\geqslant 32^{\circ} \mathrm{C}$ and odd-numbered years had fewer. Overall, CAS, HJA, and TYE had the highest \# DAYS $\geqslant 32^{\circ} \mathrm{C}$, while OCR, CLE, and OLY had relatively few.

Drought conditions were recorded at OCR and CAS in 1992, at CLE in 1994, and at CLE and CAS in 2000 and 2001. Unusually wet conditions were recorded at TYE, HJA, OLY, and CAS between 1994 and 1997. The SOI and PDO indices measured climate conditions at larger spatial scales, reflecting climate conditions across the Pacific region. Thus, SOI and PDO values did not vary by study area. Strong El Niño conditions (SOI $\leqslant-1.0$ ) occurred in 1986, 1991, and 1997, and moderate El Niño conditions occurred in 1992-1994, 2002, and 2004. Strong La Niña conditions (SOI $\geqslant 1.0$ ) occurred in 1988-1989 and 1998-2000. The PDO generally follows a longer cycle than SOI, cycling over decades rather than years. During our study, the PDO remained primarily in the warm phase, but switched to the cool phase in 1988-1990 and 1998-2001.

\subsection{Climate factors associated with survival and recruitment}

\subsubsection{Annual survival}

For the Washington study areas (OLY, CLE), the top model contained combinations of 2 a priori hypotheses for annual survival, while the top models for the Oregon areas represented a single cli- mate hypothesis (Table 1). The growing season moisture hypothesis received most support at OLY, CLE, and OCR (Table 1). At all three areas, the covariate that best quantified this association was PDSI. Survival was positively associated with wetter-than-normal growing season conditions at all three areas, although at OCR there was also an interaction between PDSI and BO where the positive association between annual survival and wet growing season conditions decreased as the proportion of spotted owl territories with barred owl detections increased (Table 2). At OLY, there was also a negative association between annual survival and the number of storms during winter (Table 2). At CLE, there was a quadratic relationship between survival and the number of storms during the nesting period. Survival was lower during years with lower or higher than average numbers of stormy days (Table 2). At TYE, the climate cycle hypothesis received the most support. Survival was highest during years when the SOI was in the cool, wet (la Niña) phase and the PDO was in the warm phase (Table 2). At the most southern study area (CAS), survival was negatively associated with hot summer days (Table 2). None of the climate hypotheses received support at HJA (Table 1).

\subsubsection{Recruitment}

Among the a priori hypotheses, the growing season moisture hypotheses had greatest support at OLY, CLE, and CAS (Table 1). At OLY, we observed a quadratic relation between recruitment and precipitation during the growing season 2 years prior (Table 2) where recruitment was higher following years of either lowerthan-normal or higher-than-normal precipitation (Table 2). At CLE, recruitment was positively associated with wet growing seasons (PDSI) 3 years prior, while at CAS, recruitment was positively associated with PDSI 2 years prior. At OCR, we observed a positive relationship between the PDSI in the previous year in a competing model, but not in the top model (Table 1).

The hypothesis representing negative associations with cold/ wet/stormy nesting seasons received support at HJA, OCR, and TYE (Table 2). At these three areas, recruitment was negatively associated with precipitation during the early nesting season, although the $95 \% \mathrm{CI}$ for beta estimate at HJA overlapped zero (Table 2). There was also some support for a positive relation with early nesting season temperature $(\hat{\beta}=0.101, \mathrm{SE}=0.158,95 \% \mathrm{CI}$ : -0.210 to 0.411 ), and a negative association with late nesting season precipitation $(\hat{\beta}=-0.007, \mathrm{SE}=0.021,95 \% \mathrm{CI}$ : -0.048 to 0.034$)$ in competing models at OCR. At CAS, there was support for the winter weather hypothesis, as we observed a quadratic relation between both winter precipitation and winter storms 2 years prior at CAS (Table 2). At TYE, recruitment was also positively associated with la Niña conditions and the cool, wet phase of the PDO 2 years prior (Table 2).

\subsection{Demographic factors associated with survival, recruitment, and resighting}

Annual survival was negatively associated with the proportion of spotted owl territories containing barred owl detections at OLY and OCR (Table 2). Survival was higher for male owls at OLY, and was lower at HJA during years of high reproduction. Recruitment was negatively associated with barred owl presence at OLY, HJA, OCR, and TYE, and an even-odd year pattern in recruitment was evident at OLY (Table 2). Resighting probabilities were positively associated with the number of young fledged per pair per year at OLY, CLE, and TYE. Barred owls were negatively associated with resighting at OCR and TYE, but positively associated at HJA. Resighting probabilities were higher for males than females at TYE. 
Table 1

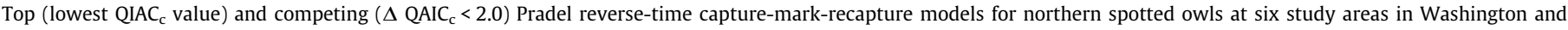
Oregon, 1990-2005.

\begin{tabular}{|c|c|c|c|c|c|}
\hline Model $^{\mathrm{a}, \mathrm{b}}$ & QAIC $_{c}$ & $\Delta$ QAIC $_{\mathrm{c}}$ & $\mathrm{QAIC}_{\mathrm{c}} w$ & K & $\mathrm{Q}$ deviance \\
\hline $\begin{array}{l}\text { OLY }(\hat{c}=1.54) \\
\{\varphi(\text { sex + BO + PDSI + STORMS-W }) p(\text { REPROD }) f(\text { BO + EO + GPRE }(Q)(\operatorname{lag} 2)\} \\
\{\varphi(\text { BO + PDSI + STORMS-W } p(\text { REPROD }) f(\text { BO + EO + GPRE }(Q)(\operatorname{lag} 2)\} \\
\{\varphi(\text { sex + BO + PDSI + STORMS-W }) p(\text { REPROD }) f(\text { BO + GPRE }(Q)(\operatorname{lag} 2)\}\end{array}$ & $\begin{array}{l}3080.71 \\
3080.83 \\
3081.38\end{array}$ & $\begin{array}{l}0.00 \\
0.12 \\
0.67\end{array}$ & $\begin{array}{l}0.32 \\
0.30 \\
0.23\end{array}$ & $\begin{array}{l}12 \\
11 \\
11\end{array}$ & $\begin{array}{l}903.27 \\
905.42 \\
905.97\end{array}$ \\
\hline $\begin{array}{l}\operatorname{CLE}(\hat{c}=1.00) \\
\{\varphi(\text { PDSI + STORMS-N(Q)) } p(\text { REPROD }) f(\text { PDSI }(\operatorname{lag} 3))\} \\
\{\varphi(\text { PDSI + STORMS-N(Q)) } p(\text { REPROD }) f(\text { SNOW + PDSI }(\text { lag3 }))\}\end{array}$ & $\begin{array}{l}\mathrm{AIC}_{\mathrm{C}} \\
1461.86 \\
1462.37\end{array}$ & $\begin{array}{l}\Delta \mathrm{AIC}_{\mathrm{c}} \\
0.00 \\
0.51\end{array}$ & $\begin{array}{l}\mathrm{AIC}_{\mathrm{c}} w \\
0.40 \\
0.31\end{array}$ & $\begin{array}{l}K \\
8 \\
9\end{array}$ & $\begin{array}{l}\text { Deviance } \\
432.67 \\
431.13\end{array}$ \\
\hline $\begin{array}{l}\text { HJA }(\hat{c}=1.56) \\
\{\varphi(\text { REPROD }) \text { p (BO)f(exp + BO (lag1) + ENPRE }(\operatorname{lag} 1))\} \\
\{\varphi(\text { REPROD }) p(\text { BO }) f(\exp +\text { BO }(\operatorname{lag} 1)+\text { WTMIN }(\operatorname{lag} 1))\} \\
\{\varphi(\text { REPROD }) p(\text { BO }) f(\exp +\text { BO }(\operatorname{lag} 1)+\text { WTMIN }(\operatorname{lag} 1)+\text { ENPRE }(\operatorname{lag} 1))\}\end{array}$ & $\begin{array}{l}\mathrm{QAIC}_{\mathrm{c}} \\
2759.54 \\
2760.30 \\
2760.30\end{array}$ & $\begin{array}{l}\triangle \text { QAIC }_{\mathrm{c}} \\
0.00 \\
0.76 \\
0.76\end{array}$ & $\begin{array}{l}\text { QAIC }_{c} w \\
0.19 \\
0.13 \\
0.13\end{array}$ & $\begin{array}{l}\text { K } \\
8 \\
8 \\
9\end{array}$ & $\begin{array}{l}\text { Q Deviance } \\
818.72 \\
819.47 \\
817.46\end{array}$ \\
\hline $\begin{array}{l}\left\{\varphi(\text { REPROD }) p(\text { BO }) f\left(\exp +\mathrm{BO}(\operatorname{lag} 1)+\text { ENPRE }(\operatorname{lag} 1)+\text { ENTMIN }(\operatorname{lag} 1)+\left(\text { ENTMIN }^{*} \text { ENPRE }\right)(\operatorname{lag} 1)\right\}\right. \\
\{\varphi \text { (REPROD) } p(\text { BO }) f(\exp +\mathrm{BO}(\operatorname{lag} 1))\} \\
\{\varphi \text { (REPROD) } p(\text { BO }) f(\exp +\mathrm{BO}(\operatorname{lag} 1)+\text { PDO }(\operatorname{lag} 1)\} \\
\{\varphi \text { (REPROD + ENPRE } p(\text { BO }) f(\exp +\mathrm{BO}(\operatorname{lag} 1)+\text { ENPRE}(\operatorname{lag} 1)\}\end{array}$ & $\begin{array}{l}2760.73 \\
2760.89 \\
2760.92 \\
2761.04\end{array}$ & $\begin{array}{l}1.19 \\
1.35 \\
1.38 \\
1.50\end{array}$ & $\begin{array}{l}0.11 \\
0.10 \\
0.10 \\
0.09\end{array}$ & $\begin{array}{l}10 \\
7 \\
8 \\
9\end{array}$ & $\begin{array}{l}815.87 \\
822.09 \\
820.09 \\
818.19\end{array}$ \\
\hline $\begin{array}{l}\text { OCR }(\hat{c}=2.52) \\
\{\varphi(\text { BO*PDSI } p(\text { BO }) f(\text { BO + ENPRE }(\operatorname{lag} 1))\} \\
\{\varphi(\text { BO*PDSI }) p(\text { BO } f(\text { BO + ENPRE }(\operatorname{lag} 1)+\text { ENTMIN }(\operatorname{lag} 1))\} \\
\{\varphi(\text { BO*PDSI }) p(\text { BO }) f(\text { BO + ENPRE }(\operatorname{lag} 1)+\text { PDSI }(\operatorname{lag} 1))\} \\
\{\varphi(\text { BO*PDSI }) p(\text { BO } f(\text { BO + ENPRE }(\operatorname{lag} 1)+\text { LNPRE }(\operatorname{lag} 1))\}\end{array}$ & $\begin{array}{l}1912.83 \\
1914.43 \\
1914.56 \\
1914.73\end{array}$ & $\begin{array}{l}0.00 \\
1.61 \\
1.74 \\
1.91\end{array}$ & $\begin{array}{l}0.33 \\
0.15 \\
0.14 \\
0.13\end{array}$ & $\begin{array}{l}9 \\
10 \\
10 \\
10\end{array}$ & $\begin{array}{l}410.81 \\
410.40 \\
410.53 \\
410.70\end{array}$ \\
\hline $\begin{array}{l}\text { TYE }(\hat{c}=1.30) \\
\{\varphi(\text { SOI }(\operatorname{lag} 1)+\text { PDO }(\operatorname{lag} 1)) p(\operatorname{sex}+\text { REPROD }) f(\text { BO }(\operatorname{lag} 1)+\text { PDO }((\operatorname{lag} 2)+\text { ENPRE }(\operatorname{lag} 1)+\text { SOI }((\operatorname{lag} 1)\} \\
\{\varphi(\text { SOI }(\operatorname{lag} 1)+\text { PDO }(\operatorname{lag} 1)) p(\operatorname{sex}+\text { REPROD }) f(\text { BO }(\operatorname{lag} 1)+\operatorname{PDO}((\operatorname{lag} 2))+\text { ENPRE }(\operatorname{lag} 1))\}\end{array}$ & $\begin{array}{l}3158.57 \\
3159.02\end{array}$ & $\begin{array}{l}0.00 \\
0.45\end{array}$ & $\begin{array}{l}0.44 \\
0.35\end{array}$ & $\begin{array}{l}11 \\
10\end{array}$ & $\begin{array}{l}559.45 \\
561.92\end{array}$ \\
\hline $\begin{array}{l}\operatorname{CAS}(\hat{c}=1.84) \\
\left\{\varphi\left(\text { DAYS } \geqslant 32^{\circ} \mathrm{C}\right) p(\mathrm{~T}) f(\exp +\text { WPRE }(\mathrm{Q})(\operatorname{lag} 2)+\text { STORMS-W }(\mathrm{Q})(\text { lag2 })+\text { PDSI (lag2 })\right\} \\
\left\{\varphi\left(\text { DAYS } \geqslant 32^{\circ} \mathrm{C}\right) p(\mathrm{~T}) f(\exp +\text { PDSI }(\text { lag } 2)\}\right.\end{array}$ & $\begin{array}{l}2283.24 \\
2287.96\end{array}$ & $\begin{array}{l}0.00 \\
4.72\end{array}$ & $\begin{array}{l}0.70 \\
0.07\end{array}$ & $\begin{array}{l}11 \\
7\end{array}$ & $\begin{array}{l}616.43 \\
629.25\end{array}$ \\
\hline
\end{tabular}

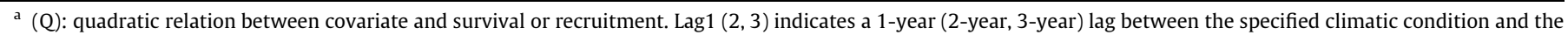
effect on the demographic parameter.

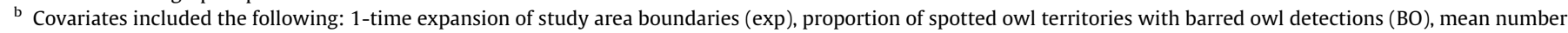

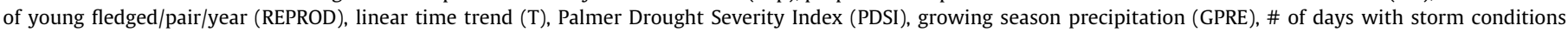

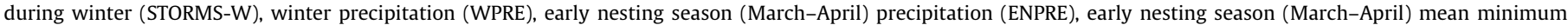

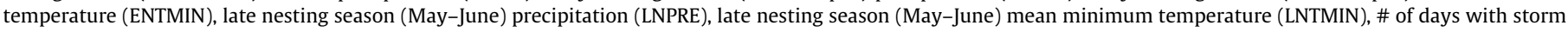

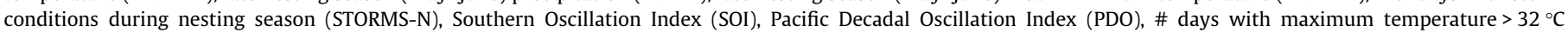
(DAYS $>32^{\circ} \mathrm{C}$ ), total winter snowfall (SNOW), and winter mean minimum temperature (WTMIN).

\subsection{Annual rate of population change and climate}

Mean estimates of $\lambda$ were $<1.0$ at all study areas, but $95 \%$ confidence intervals overlapped 1.0 for OLY and TYE (Table 3). Mean $\lambda$ was highest at TYE $\hat{\lambda}=0.986, \mathrm{SE}=0.015$ ) and lowest at CLE $(\hat{\lambda}=0.920, \mathrm{SE}=0.016)$ (Table 3$)$. Year-specific estimates indicated a decline in $\lambda$ over time at CLE, HJA, and OCR (Fig. 1B-D). Year-specific estimates of $\lambda$ were highly variable at OLY (range: $0.63-1.23$ ) and CAS (range: $0.81-1.23$ ) (Fig. $1 \mathrm{~A}$ and $\mathrm{F}$ ) and least variable at TYE (range: 0.92-1.07) and CLE (range: 0.87-1.04) (Fig. 1B and E).

Associations between $\hat{\lambda}$ and climate were a function of the climate associations with survival and recruitment. We observed associations with climate on both survival and recruitment at all areas except HJA, where only recruitment was associated with climate. At OLY, $\hat{\lambda}$ was highest when growing season conditions were wetter-than-normal and the number of winter storm days was low, although recruitment was somewhat lower when growing seasons during the previous year had high precipitation. Similarly, $\hat{\lambda}$ was highest at CLE when growing seasons were wetter-than-normal and the number of nesting season storm days was moderate. At HJA, $\hat{\lambda}$ was negatively related to early nesting season precipitation in the previous year, while $\hat{\lambda}$ at OCR was negatively related to nesting season precipitation but also positively related to wetterthan-normal growing season conditions. At TYE, $\hat{\lambda}$ was highest following years when the SOI was in the el Niño phase and the PDO was in the cool, wet phase which occurred in 1989-1991 and 1998-1999. Similar to HJA and OCR, $\hat{\lambda}$ at TYE was lower following years with high nesting season precipitation. At CAS, $\hat{\lambda}$ was highest following years with wetter-than-normal growing seasons, lower amounts of winter precipitation, and fewer DAYS $>32^{\circ} \mathrm{C}$.

\subsection{Relative contributions of survival and recruitment to $\lambda$}

Time-specific seniority estimates $\left(\hat{\gamma}_{t}\right)$ indicated that the relative contribution of survival to $\lambda(\sim 0.90)$ was much greater than recruitment $(\sim 0.10)$ for all areas although relative contributions of survival and recruitment to $\lambda$ varied over time (range: $0.76-$ 0.99 ) and among study areas (Fig. 2, Supplementary Information 5 ). Year-to-year variation in seniority was greatest at OLY and CAS and least at CLE and OCR (Fig. 2). Years during which $\hat{\lambda}_{t}>1.0$ were those during which recruitment was higher than average (Fig. 1), particularly for OLY, TYE, and CAS.

\subsection{Variance components}

The top models accounted for $30-87 \%$ of the temporal process variation in $\hat{\lambda}$, with climate accounting for $8-85 \%$ of this variation (Table 4). Climate accounted for the most temporal variation in $\hat{\lambda}$ at TYE (85\%) and OCR (78\%), and least at HJA (3\%) and CLE (8\%). The top models accounted for $2-100 \%$ of the temporal variation in annual survival, with climate accounting for $0-67 \%$ (Table 4). Climate accounted for a substantial amount of variation in survival only at OLY (67\%), while the combined effects of barred owls and climate accounted for most ( $100 \%$ ) of the temporal process variation in survival at OCR. For recruitment, the top models accounted for $2-92 \%$ of the temporal process variation, with climate account- 
Table 2

Parameter estimates from top (lowest $\mathrm{AIC}_{\mathrm{c}}$ ) Pradel reverse-time capture-markrecapture models for northern spotted owls at six study areas in Washington and Oregon, 1990-2005.

\begin{tabular}{|c|c|c|c|c|c|}
\hline & \multirow[t]{2}{*}{ Parameter $^{\mathrm{a}}$} & \multirow[t]{2}{*}{ Estimate } & \multirow[t]{2}{*}{ SE } & \multicolumn{2}{|l|}{$95 \% \mathrm{CI}$} \\
\hline & & & & Lower & Upper \\
\hline \multirow[t]{12}{*}{ OLY } & $\varphi$ Intercept & 3.244 & 0.404 & 2.453 & 4.036 \\
\hline & $\varphi$ Sex & 0.210 & 0.144 & -0.072 & 0.492 \\
\hline & $\varphi \mathrm{BO}$ & -6.368 & 2.064 & -10.414 & -2.323 \\
\hline & $\varphi$ PDSI & 0.202 & 0.083 & 0.039 & 0.365 \\
\hline & $\varphi$ STORMS-W & -0.061 & 0.019 & -0.099 & -0.023 \\
\hline & $p$ Intercept & 0.657 & 0.108 & 0.444 & 0.869 \\
\hline & $p$ REPROD & 0.668 & 0.166 & 0.342 & 0.993 \\
\hline & $f$ Intercept & 5.571 & 2.240 & 1.180 & 9.962 \\
\hline & $f \mathrm{BO}$ & -16.329 & 4.644 & -25.431 & -7.226 \\
\hline & $f \mathrm{EO}$ & -0.583 & 0.380 & -1.329 & 0.162 \\
\hline & $f$ GPRE & -0.134 & 0.047 & -0.226 & -0.042 \\
\hline & $f \mathrm{GPRE}^{2}$ & 0.001 & 0.000 & 0.000 & 0.001 \\
\hline \multirow[t]{8}{*}{ CLE } & $\varphi$ Intercept & 1.492 & 0.214 & 1.072 & 1.912 \\
\hline & $\varphi$ PDSI & 0.155 & 0.079 & 0.000 & 0.310 \\
\hline & $\varphi$ STORMS-N & 0.534 & 0.260 & 0.023 & 1.044 \\
\hline & $\varphi$ STORMS-N ${ }^{2}$ & -0.101 & 0.051 & -0.200 & -0.001 \\
\hline & $p$ Intercept & 1.624 & 0.279 & 1.078 & 2.171 \\
\hline & $p$ REPROD & 0.583 & 0.289 & 0.016 & 1.151 \\
\hline & $f$ Intercept & -2.164 & 0.136 & -2.430 & -1.897 \\
\hline & $f$ PDSI ( 3 year lag) & 0.216 & 0.101 & 0.017 & 0.415 \\
\hline \multirow[t]{8}{*}{ HJA } & $\varphi$ Intercept & 2.533 & 0.201 & 2.139 & 2.927 \\
\hline & $\varphi$ REPROD & -0.849 & 0.253 & -1.345 & -0.352 \\
\hline & $p$ Intercept & 1.605 & 0.157 & 1.297 & 1.914 \\
\hline & $p$ BO & 3.357 & 1.817 & -0.205 & 6.918 \\
\hline & $f$ Intercept & -0.386 & 0.657 & -1.673 & 0.901 \\
\hline & $f$ Exp & 1.242 & 0.436 & 0.387 & 2.097 \\
\hline & $f$ BO (lag1) & -25.049 & 5.157 & -35.157 & -14.941 \\
\hline & $f$ ENPRE(lag1) & -0.025 & 0.014 & -0.053 & 0.003 \\
\hline \multirow[t]{9}{*}{ OCR } & $\varphi$ Intercept & 2.263 & 0.232 & 1.807 & 2.718 \\
\hline & $\varphi$ BO & -2.607 & 1.386 & -5.324 & 0.109 \\
\hline & $\varphi$ PDSI & 0.198 & 0.090 & 0.022 & 0.374 \\
\hline & $\varphi$ BO*PDSI & -1.188 & 0.693 & -2.546 & 0.170 \\
\hline & $p$ Intercept & 2.328 & 0.220 & 1.898 & 2.759 \\
\hline & $p$ BO & -1.160 & 0.793 & -2.714 & 0.393 \\
\hline & $f$ Intercept & -0.672 & 0.524 & -1.699 & 0.354 \\
\hline & $f \mathrm{BO}$ & -2.894 & 0.841 & -4.543 & -1.245 \\
\hline & $f$ ENPRE (lag1) & -0.029 & 0.012 & -0.053 & -0.004 \\
\hline \multirow[t]{11}{*}{ TYE } & $\varphi$ Intercept & 1.934 & 0.089 & 1.761 & 2.108 \\
\hline & $\varphi$ SOI lag & 0.308 & 0.122 & 0.069 & 0.548 \\
\hline & $\varphi$ PDO lag & 0.204 & 0.116 & -0.023 & 0.431 \\
\hline & $p$ Intercept & 1.798 & 0.402 & 1.010 & 2.586 \\
\hline & $p$ Sex & 0.627 & 0.270 & 0.098 & 1.156 \\
\hline & $p$ REPROD & 1.299 & 0.662 & 0.001 & 2.598 \\
\hline & $f$ Intercept & -0.709 & 0.361 & -1.417 & -0.001 \\
\hline & $f$ BO (lag1) & -6.651 & 1.336 & -9.269 & -4.033 \\
\hline & $f$ PDO (lag2) & -0.203 & 0.125 & -0.448 & 0.043 \\
\hline & $f$ ENPRE (lag1) & -0.031 & 0.014 & -0.058 & -0.004 \\
\hline & $f$ SOI (lag2) & 0.172 & 0.109 & -0.041 & 0.385 \\
\hline \multirow[t]{11}{*}{ CAS } & $\varphi$ Intercept & 3.410 & 0.613 & 2.209 & 4.611 \\
\hline & $\varphi$ DAYS $\geqslant 32^{\circ} \mathrm{C}$ & -0.057 & 0.019 & -0.095 & -0.019 \\
\hline & $p$ Intercept & 0.468 & 0.201 & 0.074 & 0.863 \\
\hline & $p \mathrm{~T}$ & 0.128 & 0.027 & 0.076 & 0.181 \\
\hline & $f$ Intercept & 1.815 & 1.558 & -1.239 & 4.870 \\
\hline & $f$ Expansion year & 2.067 & 0.541 & 1.006 & 3.127 \\
\hline & $f$ WPRE (lag2) & -0.177 & 0.075 & -0.324 & -0.030 \\
\hline & $f$ WPRE $^{2}$ (lag2) & 0.001 & 0.001 & 0.000 & 0.002 \\
\hline & f STORMS-W (lag2) & 0.274 & 0.192 & -0.102 & 0.649 \\
\hline & $f$ STORMS-W ${ }^{2}(\operatorname{lag} 2)$ & -0.010 & 0.008 & -0.027 & 0.006 \\
\hline & $f$ PDSI (lag2) & 0.276 & 0.087 & 0.106 & 0.446 \\
\hline
\end{tabular}

a Covariates included the following: proportion of spotted owl territories with barred owl detections (BO), mean number of young fledged/pair/year (REPROD), linear time trend (T), Palmer Drought Severity Index (PDSI), growing season precipitation (GPRE), \# of days with storm conditions during winter (STORMS-W), winter precipitation (WPRE), early nesting season (March-April) precipitation (ENPRE), early nesting season (March-April) mean minimum temperature (ENTMIN), late nesting season (May-June) precipitation (LNPRE), late nesting season (May-June) mean minimum temperature (LNTMIN), \# of days with storm conditions during nesting season (STORMS-N), Southern Oscillation Index (SOI), Pacific Decadal Oscillation Index (PDO), \# days with max temperature $>32^{\circ} \mathrm{C}$ (DAYS $>32^{\circ} \mathrm{C}$ ), total winter snowfall $(\mathrm{SNOW})$, winter mean minimum temperature (WTMIN).
Table 3

Mean estimates for $\hat{\lambda}$, survival, recruitment, and resighting of northern spotted owls on six study areas in Washington and Oregon, 1990-2005. Mean values were obtained from the random effects models.

\begin{tabular}{|c|c|c|c|c|c|c|c|c|}
\hline & \multicolumn{2}{|l|}{$\lambda$} & \multicolumn{2}{|l|}{$\varphi$} & \multicolumn{2}{|l|}{$f$} & \multicolumn{2}{|l|}{$p$} \\
\hline & Mean & SE & Mean & SE & Mean & SE & Mean & SE \\
\hline OLY & 0.966 & 0.0210 & 0.869 & 0.023 & 0.093 & 0.022 & 0.893 & 0.075 \\
\hline CLE & 0.919 & 0.0155 & 0.834 & 0.014 & 0.079 & 0.011 & 0.892 & 0.033 \\
\hline HJA & 0.955 & 0.0178 & 0.885 & 0.009 & 0.072 & 0.014 & 0.916 & 0.047 \\
\hline OCR & 0.961 & 0.0190 & 0.878 & 0.011 & 0.083 & 0.012 & 0.898 & 0.042 \\
\hline TYE & 0.986 & 0.0149 & 0.872 & 0.009 & 0.120 & 0.016 & 0.871 & 0.046 \\
\hline CAS & 0.947 & 0.0131 & 0.852 & 0.012 & 0.093 & 0.025 & 0.887 & 0.086 \\
\hline
\end{tabular}

ing for $2-51 \%$ (Table 4). Climate accounted for $51 \%$ at CAS, $48 \%$ at OLY, $44 \%$ at TYE, and $25 \%$ at OCR. Relatively low amounts of variation in recruitment were accounted for by climate for CLE (2\%) or HJA (6\%).

\section{Discussion}

This is the first study to examine associations between rate of population change and climate for the northern spotted owl and to consider such associations across a broad geographic range. We established new associations between survival, recruitment and rate of population change and moisture conditions during the growing season, regional climate cycles, and hot summer days not previously reported for this subspecies. While we observed relationships between demographic rates and local weather during the winter and nesting season similar to those of earlier studies (Franklin et al., 2000; Olson et al., 2004; Dugger et al., 2005), these models generally received far less support than those representing regional moisture conditions and climate cycles at most study areas. Although population growth rates were associated with climate at all six study areas, the specific climatic factors, the strength of the relationships, and the amount of temporal variation accounted for by climate varied among areas. As predicted, climate accounted for more variability in recruitment than survival, while $\lambda$ was most sensitive to changes in adult survival. Franklin et al. (2000) suggested that northern spotted owls follow a bet-hedging life history strategy, where selection favors individuals that increase their odds of survival by reproducing only during favorable conditions. Our results were consistent with this hypothesis; however, we found that relative contributions of survival and recruitment to rate of population growth varied geographically and temporally. These differences may reflect variation in prey availability, habitat quality, environmental conditions, or life history strategies across the range of the subspecies.

\subsection{Regional climate}

At four study areas, $\lambda$ was positively associated with wetterthan-normal conditions during the growing season, either through associations with annual survival, recruitment, or both. Year-specific survival rates were related to moisture conditions during the current year, while recruitment reflected moisture conditions 2-3 years prior, which likely influenced survival of juveniles from prior years' reproduction. Similarly, survival, recruitment, and $\lambda$ at TYE were associated with the Southern Oscillation and Pacific Decadal Oscillation while at CAS, $\lambda$ was negatively associated with summer temperature. Our a priori hypotheses regarding regional climate cycles, growing season moisture, and to some extent hot summer days postulated that climate affected spotted owl population dynamics by influencing prey abundance rather than through direct effects of weather on owls, and our results supported this hypothesis at OLY, CLE, OCR, TYE and CAS. 
A.OLY

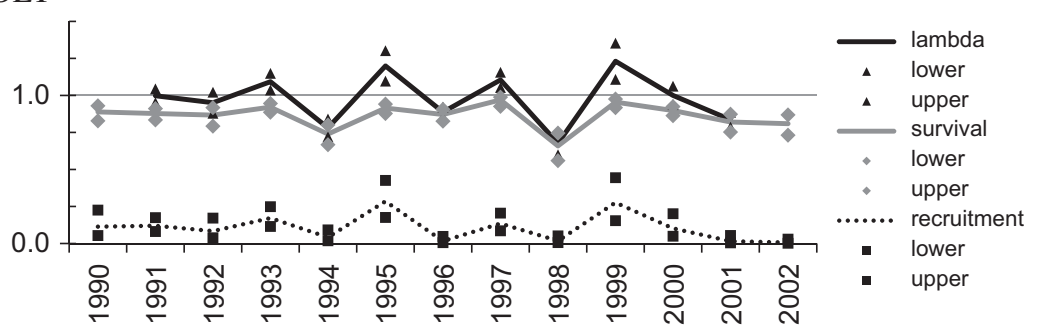

B. CLE

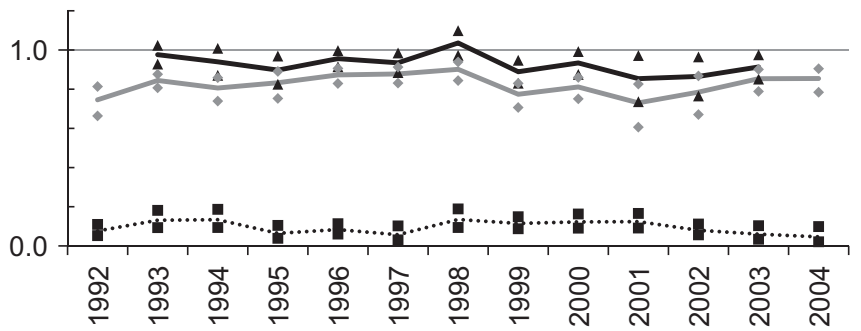

C. HJA

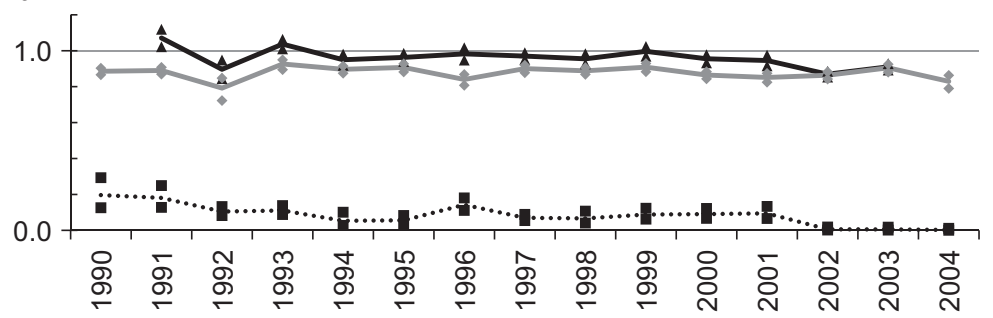

D.OCR

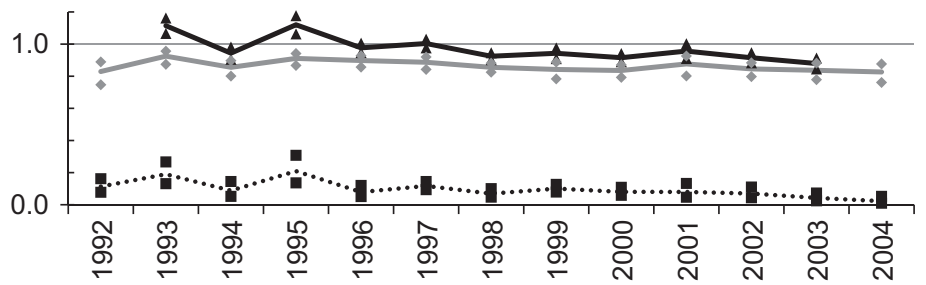

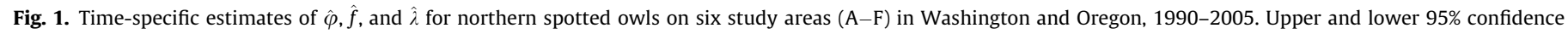
intervals are indicated for each rate.

Both annual survival and reproductive success in raptors has frequently been associated with prey availability (Newton, 1979). Population sizes of northern flying squirrels (Glaucomys sabrinus), deer mice (Peromyscus maniculatus), and other mammal species that comprise spotted owl diets are often characterized by large annual variations in population size driven primarily by food availability (Ransome and Sullivan, 1997; Waters and Zabel, 1998; Gomez et al., 2005). Variation in weather can have substantial influence on food availability for small mammals. Small mammal populations have shown declines during drought (Spevak, 1983), and population dynamics have been shown to be associated with regional climate cycles such as the SOI (Lima et al., 2001). Northern flying squirrels feed primarily on hypogeous fungi (Gomez et al., 2005), which are most abundant during mesic conditions particularly during late summer and fall (Luoma et al., 2003). Similar to our results, annual survival and fecundity of Mexican spotted owls (Strix occidentalis lucida) were positively associated with precipitation during the previous year (Seamans et al., 2002). Few studies of small mammal population dynamics have been conducted within the range of the northern spotted owl. Rosenberg et al. (2003) found a positive relationship between spotted owl reproduction and abundance of deer mice at HJA and suggested that interactions between small mammal populations and weather may influence prey availability for spotted owls. However, without studies that specifically identify responses of small mammal populations to climate variability at these areas, we can only speculate about the causal mechanisms that may link climate, small mammals, and spotted owl population dynamics.

Population growth rate was negatively associated with hot summer temperatures at CAS, which was the southernmost area and had the greatest number of days with temperatures $\geqslant 32{ }^{\circ} \mathrm{C}$ in all years. Although Forsman et al. (1984), Barrows and Barrows (1978), and Weathers et al. (2001) all reported that spotted owls become stressed at temperatures above $28^{\circ} \mathrm{C}$, there is no evidence to indicate that they are ever directly killed by temperatures normally encountered within their range because they are able to thermoregulate by seeking out shady roosts in the forest understory on hot days (Forsman et al., 1984; Barrows and Barrows, 


\section{E. TYE}

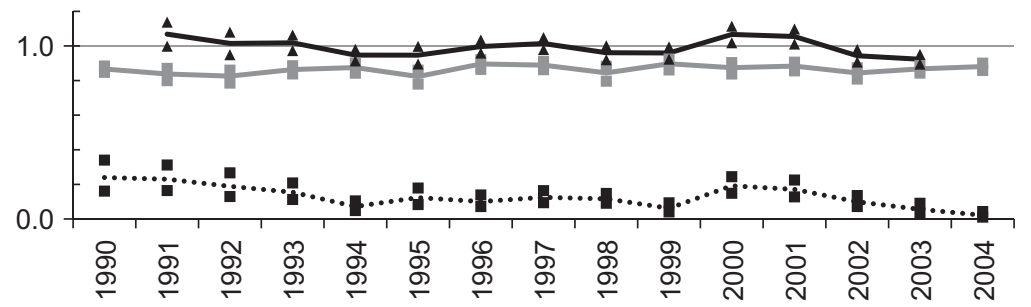

\section{F. CAS}

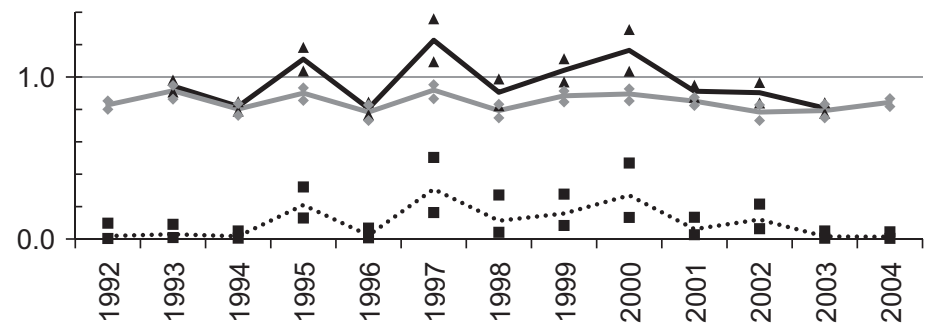

Fig. 1 (continued)

A. Washington study areas

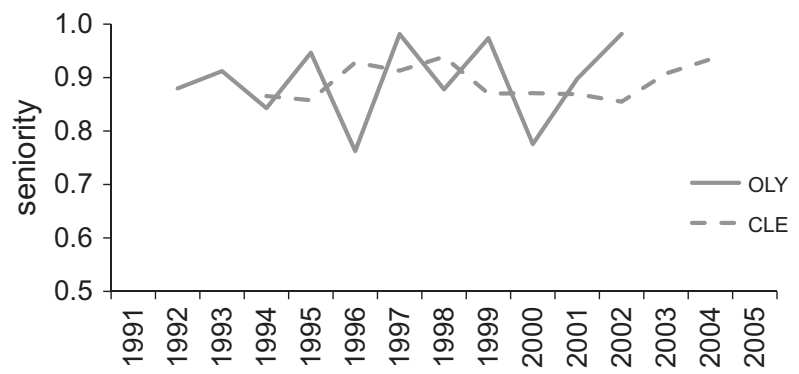

B. Oregon study areas

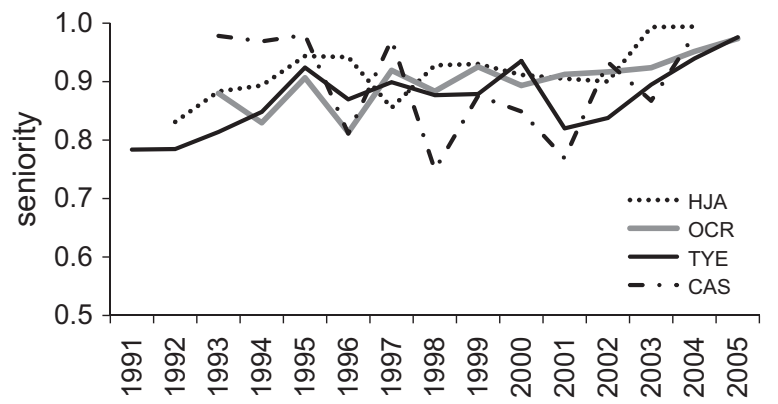

Fig. 2. Estimates of seniority for northern spotted owls at six study areas in Washington (A) and Oregon (B), 1990-2005.

1978). While the number of days $\geqslant 32{ }^{\circ} \mathrm{C}$ was a measure of local weather, it is possible that summers with many hot days are associated with reduced prey populations or foraging success, consequently reducing survival and population growth of spotted owls.

\subsection{Local weather}

Although wetter-than-average conditions during the growing season appeared to be beneficial for spotted owls, heavy precipita- tion during the early nesting season did not. While annual survival was more closely related to regional climate conditions, recruitment was often associated with local weather. We found negative associations between recruitment and heavy nesting season precipitation at OCR, TYE, and HJA. During this period, owls initiate nesting and incubate eggs (Forsman et al., 1984). Energy demands on adults can be higher during nesting seasons, and severe, winterlike conditions can decrease prey abundance, prey availability, and foraging success (Forsman et al., 1984). We also observed quadratic associations with winter precipitation and storms at CAS. Negative associations between spotted owl survival or reproduction and severe weather during the nesting season or winter have been documented in other studies (Franklin et al., 2000; Olson et al., 2004; Dugger et al., 2005; Glenn, 2009); however, ours is the first study to suggest similar relationships in the context of $\lambda$.

\subsection{Barred owls}

We found a negative association between the proportion of spotted owl territories with barred owl detections (BO) and annual survival at OLY and OCR. On most study areas, we found that BO was either negatively associated with resighting probabilities (OLY, CLE, OCR, CAS) or not associated with resighting probabilities (TYE). The exception was the HJA study area where the association between $\mathrm{BO}$ and resighting probability was positive. Although annual reproduction of northern spotted owls is highly variable (Anthony et al., 2006), recruitment of new individuals into the territorial population in our study was less variable. At these six study areas, a negative association between numbers of young fledged per pair per year and the BO covariate was detected only at OLY (Glenn, 2009). However, recruitment was negatively associated with BO at OLY, HJA, OCR, and TYE. This suggests that barred owls may have a negative effect on rates of population change of spotted owls primarily by influencing recruitment as opposed to reproduction. These results are consistent with Olson et al. (2005) and Kelly et al. (2003), who reported that barred owls were associated with decreased territory occupancy of spotted owls. Olson et al. (2005) also reported that barred owl presence was related to increased local (territory) extinction at TYE and OCR, and also to decreased local colonization probabilities at HJA. Why relation- 
Table 4

Estimated variance components for top Pradel survival and recruitment models for northern spotted owls on six study areas in Washington and Oregon, $1990-2005$.

\begin{tabular}{|c|c|c|c|c|c|c|c|c|c|}
\hline & $\sigma_{\text {temporal process }}^{2}$ & $95 \% \mathrm{CI}$ & $\sigma_{\text {model }}^{2}$ & $95 \% \mathrm{CI}$ & $\%$ & $\sigma_{\text {climate }}^{2}$ & $\%$ & $\sigma_{\text {demographic factors }}^{2}$ & $\%$ \\
\hline \multicolumn{10}{|c|}{ Variance components for $\lambda$} \\
\hline OLY & 0.031 & $0.009-0.070$ & 0.021 & $0.008-0.068$ & 67 & 0.012 & 40 & 0.0086 & 28 \\
\hline CLE & 0.003 & $-0.0002-0.013$ & 0.001 & $0.000-0.006$ & 30 & 0.0002 & 8 & na & na \\
\hline HJA & 0.005 & $0.001-0.017$ & 0.003 & $0.001-0.010$ & 66 & 0.0001 & 3 & 0.0032 & 63 \\
\hline OCR & 0.003 & $-0.001-0.018$ & 0.003 & $0.0001-0.014$ & 78 & 0.003 & 78 & $2.8 \mathrm{E}-06$ & 0 \\
\hline TYE & 0.003 & $0.0005-0.010$ & 0.002 & $0.001-0.007$ & 87 & 0.002 & 85 & 0.0001 & 3 \\
\hline CAS & 0.025 & $0.009-0.081$ & 0.013 & $0.004-0.047$ & 53 & 0.013 & 53 & na & na \\
\hline \multicolumn{10}{|c|}{ Variance components for survival } \\
\hline OLY & 0.007 & $0.003-0.022$ & 0.005 & $0.001-0.018$ & 67 & 0.005 & 67 & $2.0 \mathrm{E}-05$ & 0 \\
\hline CLE & 0.006 & $0.002-0.021$ & 0.0001 & $0.000-0.004$ & 2 & 0.0001 & 2 & na & na \\
\hline HJA & 0.003 & $0.001-0.009$ & $5.0 \mathrm{E}-05$ & $0.000-0.002$ & 7 & na & na & $5.0 \mathrm{E}-05$ & 2 \\
\hline OCR & $2.2 \mathrm{E}-05$ & $-0.001-0.004$ & $2.2 \mathrm{E}-05$ & $0.000-0.001$ & 100 & Climate*demog & & $2.2 \mathrm{E}-05$ & 100 \\
\hline TYE & $3.80 \mathrm{E}-06$ & $-0.0004-0.003$ & $3.8 \mathrm{E}-06$ & $0.000-0.0002$ & 1 & $3.8 \mathrm{E}-06$ & 1 & na & 0 \\
\hline CAS & 0.006 & $0.002-0.019$ & 0.0002 & $0.000-0.004$ & 3 & 0.0002 & 3 & na & na \\
\hline \multicolumn{10}{|c|}{ Variance components for recruitment } \\
\hline OLY & 0.018 & $0.002-0.029$ & 0.013 & $0.001-0.030$ & 70 & 0.009 & 48 & 0.0040 & 22 \\
\hline CLE & 0.002 & $0.001-0.005$ & $2.4 \mathrm{E}-05$ & $0.000-0.001$ & 2 & $2.4 \mathrm{E}-05$ & 2 & na & na \\
\hline HJA & 0.002 & $0.001-0.007$ & 0.002 & $0.001-0.007$ & 92 & $1.4 \mathrm{E}-04$ & 6 & 0.0020 & 86 \\
\hline OCR & 0.002 & $0.001-0.009$ & 0.001 & $0.0001-0.005$ & 32 & 0.001 & 26 & $1.2 \mathrm{E}-04$ & 6 \\
\hline TYE & 0.004 & $0.002-0.012$ & 0.003 & $0.001-0.009$ & 63 & 0.002 & 44 & 0.0008 & 19 \\
\hline CAS & 0.013 & $0.005-0.044$ & 0.006 & $0.002-0.024$ & 51 & 0.006 & 51 & na & na \\
\hline
\end{tabular}

ships between barred owls and spotted owl survival, resighting, and recruitment were not consistent among areas is unclear, although it is possible that the covariate we used (\% of spotted owl territories with barred owl detections for a study area in a given year) was too coarse to reflect the true impact of barred owls. Documentation of this relationship will require more consistent surveys of barred owls (Bailey et al., 2009) and may be better documented with territory-specific analyses such as those conducted by Olson et al. (2005) and Dugger et al. (2005).

\section{Conclusions}

Our study demonstrated that demographic rates of northern spotted owls are associated with local weather and regional climate, although the specific climatic factors most strongly associated with demographic rates, the relative contributions of survival and recruitment to population growth rate, and the amount of variation in demographic rates accounted for by climate varied among the six areas we examined. Additionally, we found a negative association between barred owl presence and recruitment at four areas and barred owls and survival at two areas. This study has helped expanded our understanding of both exogenous and endogenous factors that influence demographic performance of this subspecies. Most northern spotted owl populations have been declining since the mid 1990s (Forsman et al., in press). Variation in climate has the potential to strongly influence population dynamics for spotted owls; however, there are numerous other factors including habitat, barred owls, and prey that must be considered as well.

Potential consequences of global climate change on Pacific Northwest forests remain unclear. Most models predict warmer, wetter winters and hotter, drier summers for the Pacific Northwest in the first half of the 21st century (Mote et al., 2008). Given the patterns we observed during 1990-2005, increased occurrence of drought conditions during the summer has the potential to negatively affect annual survival, recruitment, and population growth rates of northern spotted owls across much of their range. Furthermore, changes in climate resulting from human activities have the potential to cause fundamentally different patterns in weather which may have unpredictable consequences for northern spotted owl populations. Given that natural resource managers cannot control climate variation and barred owls are likely to persist and increase in the range of the northern spotted owl, maintaining sufficient high quality habitat on the landscape remains the most important management strategy for the conservation of this subspecies.

\section{Acknowledgements}

Our research was funded by USDA Forest Service, USDI Bureau of Land Management, USDI National Park Service, and the National Science Foundation. We are indebted to the dedicated field crew leaders and large number of field biologists who collected the demographic data over the past several decades. Earlier drafts of this manuscript were reviewed by Gail Olson, Cliff Pereira, and George Taylor.

\section{Appendix A. Supplementary material}

Supplementary data associated with this article can be found, in the online version, at doi:10.1016/j.biocon.2010.06.021.

\section{References}

Anderson, D.R., Burnham, K.P., 1992. Demographic analysis of northern spotted owl populations. Recovery Plan for the Northern Spotted Owl, Appendix C. U.S. Fish and Wildlife Service, Portland, OR.

Anthony, R.G., Forsman, E.D., Franklin, A.B., Anderson, D.R., Burnham, K.P., White, G.C., Schwarz, C.J., Nichols, J., Hines, J.E., Olson, G.S., Ackers, S.E., Andrews, S.L., Biswell, B.L., Diller, L.V., Dugger, K.M., Fehring, K.E., Fleming, T.L., Gerhardt, R.P., Gremel, S.A., Gutiérrez, R.J., Happe, P.J., Herter, D.R., Higley, S.M., Horn, R.B., Irwin, L., Loschl, P.J., Reid, J.A., Sovern, S.G., 2006. Status and trends in demography of northern spotted owls, 1985-2003. Wildlife Monographs 163, $1-48$.

Bailey, L.L., Reid, J.A., Forsman, E.D., Nichols, J.D., 2009. Modeling co-occurrence of northern spotted and barred owls: accounting for detection probability differences. Biological Conservation 142, 2983-2989.

Barrowclough, G.F., Gutiérrez, R.J., Groth, J.G., 1999. Phylogeography of spotted owl Strix occidentalis populations based on mitochondrial DNA sequences: gene flow, genetic structure, and a novel biogeographic pattern. Evolution 53, 919931.

Barrows, C., Barrows, K., 1978. Roost characteristics and behavioral thermoregulation in the spotted owl. Western Birds 9, 1-8.

Barrows, C., Barrows, K., 1980. Feeding ecology of the spotted owl in California. Raptor Research 14, 73-78.

Blakesley, J.A., Anderson, D.R., Noon, B.R., 2006. Breeding dispersal in the California spotted owl. The Condor 108, 71-81. 
Burnham, K.P., Anderson, D.R., 2002. Model selection and multimodel inference: a practical information-theoretical approach. second ed.. Springer-Verlag, New York, New York, USA.

Burnham, K.P., Anderson, D.R., White, G.C., Brownie, C., 1987. Design and analysis of fish survival experiments based on release-recapture. American Fisheries Society, Monograph 5, Bethesda. Maryland, USA.

Burnham, K.P., Anderson, D.R., White, G.C., 1994. Estimation of vital rates of the northern spotted owl. Pages 1-26 in Appendix J of the Final Supplemental Environmental Impact Statement on Management of Habitat for Latesuccessional and Old-growth Forest Related Species Within the Range of the Northern Spotted Owl, vol. 2. US Forest Service and US Bureau of Land Management, Portland, OR, USA

Carey, A.B., Reid, J.A., Horton, S.P., 1990. Spotted owl home range and habitat use in southern Oregon Coast Ranges. Journal of Wildlife Management 54, 11-17.

Carey, A.B., Horton, S.P., Biswell, B.L., 1992. Northern spotted owls: influence of prey base and landscape character. Ecological Monographs 62, 223-250.

Courtney, S.P., Blakesley, J.A., Bigley, R.E., Cody, M.L., Dunbacher, J.P., Fleischer, R.C., Franklin, A.B., Franklin, J.F., Gutiérrez, R.J., Marzluff, L.M., Sztukowoski, L., 2004. Scientific Evaluation of the Status of the Northern Spotted Owl. Sustainable Ecosystems Institute, Portland, OR, USA.

Dugger, K.M., Wagner, F., Anthony, R.G., Olson, G.S., 2005. The relationship between habitat characteristics and demographic performance of northern spotted owls in southern Oregon. The Condor 107, 863-878.

Forsman, E.D., Meslow, E.C., Wight, H.M., 1984. Distribution and biology of the spotted owl in Oregon. Wildlife Monographs, 87

Forsman, E.D., Otto, I.A., Aubuchon, D., Lewis, J.C., Sovern, S.G., Maurice, K.J., Kaminski, T., 1994. Reproductive chronology of the northern flying squirrel on the Olympic Peninsula, Washington. Northwest Science 68, 273-276.

Forsman, E.D., Otto, I.A., Sovern, S.G., Taylor, M., Hayes, D.W., Allen, H., Roberts, S.L., Seaman, D.E., 2001. Spatial and temporal variation in diets of spotted owls in Washington. Journal of Raptor Research 35, 141-150.

Forsman, E.D., Anthony, R.G., Reid, J.A., Loschl, P.J., Sovern, S.G., Taylor, M., Biswell, B.L., Ellingson, A., Meslow, E.C., Miller, G.S., Swindle, K.A., Thrailkill, J.A., Wagner, F.F., Seaman, D.E., 2002. Natal and breeding dispersal of northern spotted owls. Wildlife Monographs 149, 1-35.

Forsman, E.D., Anthony, R.G., Meslow, E.C., Zabel, C.J., 2004. Diets and foraging behavior of northern spotted owls in Oregon. Journal of Raptor Research 38, 214-230.

Forsman, E.D., Kaminski, T.J., Lewis, J.C., Maurice, K.J., Sovern, S.G., Ferland, C., Glenn, E.M., 2005. Home range and habitat use of northern spotted owls on the Olympic Peninsula, Washington. Journal of Raptor Research 39, 365-377.

Forsman, E.D., Anthony, R.G., Dugger, K.M., Glenn, E.M., Franklin, A.B., White, G.C., Schwarz, C.J., Burnham, K.P., Anderson, D.R., Nichols, J.D., Hines, J.E., Lint, J.B., Davis, R.J., Ackers, S.H., Andrews, L.S., Biswell, B.L., Carlson, P.C., Diller, L.V., Gremel, S.A., Herter, D.R., Higley, J.M., Horn, R.B., Reid, J.A., Rockweit, J., Schaberel, J., Snetsinger, T.J., Sovern, S.G. in press. Demographic trends of northern spotted owls: a meta-analysis, 1985-2008. Studies in Avian Biology.

Franklin, A.B., Anderson, D.R., Burnham, K.P., Wagner, F.F., 1996. Methods for collecting and analyzing demographic data on the northern spotted owl. Studies in Avian Biology 17, 12-20.

Franklin, A.B., Anderson, D.R., Gutiérrez, R.J., Burnham, K.P., 2000. Climate, habitat quality, and fitness in northern spotted owl populations in northwestern California. Ecological Monographs 70, 539-590.

Franklin, J.F., Dyrness, C.T., 1973. Natural vegetation of Oregon and Washington. USDA Forest Service General Technical Report PNW-8.

Glenn. E.M., 2009. Local Weather, Regional Climate, and Population Dynamics of Northern Spotted Owls in Washington and Oregon. Ph.D. Thesis, Oregon State University, Corvallis, OR, USA.

Glenn, E.M., Hanson, M.C., Anthony, R.G., 2004. Spotted owl home range and habitat use in young forests of western Oregon. Journal of Wildlife Management 68, 33 50.

Gomez, D.M., Anthony, R.G., Hayes, J.P., 2005. Influence of thinning of Douglas-fir forests on population parameters and diet of northern flying squirrels. Journal of Wildlife Management 69, 1670-1682.
Kelly, E.G., Forsman, E.D., Anthony, R.G., 2003. Are barred owls displacing spotted owls? The Condor 105, 45-53.

Lima, M., Julliard, M., Stenseth, N.C., Jaksic, F.M., 2001. Demographic dynamics of a neotropical small rodent Phyllotis darwini: feedback structure, predation and climatic factors. Journal of Animal Ecology 70, 762-775.

Lint, J., Noon, B., Anthony, R., Forsman, E., Raphael, M., Collopy, M., Starkey, E., 1999. Northern spotted owl effectiveness monitoring plan for the Northwest Forest Plan. USDA Forest Service General Technical Report PNW-GTR-440.

Luoma, D.L., Trappe, J.M., Claridge, A.W., Jacobs, K.M., Cazares, E., 2003. Relationships among fungi and small mammals in forested ecosystems. In: Zabel, C.J., Anthony, R.G. (Eds.), Mammal Community Dynamics: Management and Conservation in the Coniferous Forests of Western North America. Cambridge University Press, Cambridge, United Kingdom, pp. 343-373.

Mote, P.W., Salathé, E.P., Dulière, V., Jump, E., 2008. Scenarios of Future Climate Change for the Pacific Northwest, Climate Impacts Group, Center for Science in the Earth System, Joint Institute for the Study of the Atmosphere and Oceans, University of Washington, Seattle, USA.

Newton, I., 1979. Population Ecology of Raptors. T. and A.D. Poyser. Berkhamted Great Britain.

Nichols, J.D., Hines, J.E., 2002. Approaches to the direct estimation of $\lambda$, and demographic contributions to $\lambda$, using capture-recapture data. Journal of Applied Statistics 29, 539-568.

Nichols, J.D., Hines, J.E., Lebreton, J.D., Pradel, R., 2000. Estimation of contributions to population growth: a reverse-time capture-recapture approach. Ecology 81, 3362-3376.

NOAA, 2008. NOAA Satellite and Information Service and the National Climatic Data Center.

Olson, G.S., Glenn, E.M., Anthony, R.G., Forsman, E.D., Reid, J.A., Loschl, P.J., Ripple W.J., 2004. Modeling demographic performance of northern spotted owls relative to forest habitat in Oregon. Journal of Wildlife Management 68, 10391053.

Olson, G.S., Anthony, R.G., Forsman, E.D., Ackers, S.H., Loschl, P.J., Reid, J.A., Dugger, K.M., Glenn, E.M., Ripple, W.J., 2005. Modeling of site occupancy dynamics for northern spotted owls, with emphasis on the effects of barred owls. Journal of Wildlife Management 69, 918-932.

Pradel, R., 1996. Utilization of capture-mark-recapture for the study of recruitment and population growth. Biometrics 52, 703-709.

Ransome, D.B., Sullivan, T.P., 1997. Food limitation and habitat preference of Glaucomys sabrinus and Tamiasciurus hudsonicus. Journal of Mammalogy 78 538-549.

Rosenberg, D.K., Swindle, K.A., Anthony, R.G., 2003. Influence of prey abundance on northern spotted owl reproductive success in western Oregon. Canadian Journal of Zoology 81, 1715-1725.

Seamans, M.E., Gutiérrez, R.J., May, C.A., 2002. Mexican spotted owl Strix occidentalis population dynamics: influence of climatic variation on survival and reproduction. The Auk 119, 321-334.

Spevak, T.A., 1983. Population changes in a Mediterranean scrub rodent assembly during drought. Southwestern Naturalist 28, 47-52.

US Department of Agriculture and US Department of the Interior, 1994. Final Supplemental Environmental Impact Statement on Management of Habitat for Late-successional and Old-growth Forest Related Species within the Range of the Northern Spotted Owl, vols. 1-2 + Record of Decision. US Forest Service and US Bureau of Land Management, Portland, Oregon, USA.

Waters, J.R., Zabel, C.J., 1998. Abundance of small mammals in fir forests in northeastern California. Journal of Mammalogy 79, 1244-1253.

Weathers, W.W., Hodum, P.J., Blakesley, J.A., 2001. Thermal ecology and ecological energetic of California spotted owls. The Condor 103, 678-690.

White, G.C., Burnham, K.P., 1999. Program MARK: survival estimation from populations of marked animals. Bird Study 46 (Suppl.), 120-138.

White, G.C., Burnham, K.P., Anderson, D.R., 2002. Advanced features of Program MARK. Pages 368-377 in R. Fields, ed. Integrating peoples and wildlife for a sustainable future. The Wildlife Society. Bethesda, MD, USA.

Zabel, C.J., McKelvey, K., Ward, J.P., 1995. Influence of primary prey on home range size and habitat-use patterns of northern spotted owls Strix occidentalis caurina. Canadian Journal of Zoology 73, 433-439. 